This item was submitted to Loughborough's Research Repository by the author.

Items in Figshare are protected by copyright, with all rights reserved, unless otherwise indicated.

\title{
Emotional intelligence in front-line/back-office employee relationships
}

PLEASE CITE THE PUBLISHED VERSION

http://dx.doi.org/10.1108/JSM-09-2016-0339

\section{PUBLISHER}

(c) Emerald

\section{VERSION}

AM (Accepted Manuscript)

\section{PUBLISHER STATEMENT}

This work is made available according to the conditions of the Creative Commons Attribution-NonCommercialNoDerivatives 4.0 International (CC BY-NC-ND 4.0) licence. Full details of this licence are available at: https://creativecommons.org/licenses/by-nc-nd/4.0/

\section{LICENCE}

CC BY-NC-ND 4.0

\section{REPOSITORY RECORD}

Kearney, T., G. Walsh, W. Barnett, T. Gong, M. Schwabe, and Kemefasu Ifie. 2019. "Emotional Intelligence in Front-line/back-office Employee Relationships". figshare. https://hdl.handle.net/2134/23945. 


\section{Loughborough University Institutional Repository}

\section{Emotional intelligence in front-line/back-office employee relationships}

This item was submitted to Loughborough University's Institutional Repository by the/an author.

Citation: KEARNEY, T. ...et al., 2017. Emotional intelligence in frontline/back-office employee relationships. Journal of Services Marketing, 31 (2), pp 161-171.

Metadata Record: https://dspace.lboro.ac.uk/2134/23945

Version: Accepted for publication

Publisher: (c) Emerald

Rights: This work is made available according to the conditions of the Creative Commons Attribution-NonCommercial-NoDerivatives 4.0 International (CC BY-NC-ND 4.0) licence. Full details of this licence are available at: https://creativecommons.org/licenses/by-nc-nd/4.0/

Please cite the published version. 


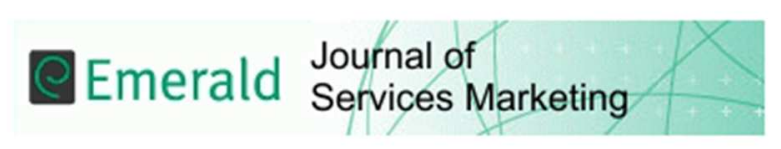

\section{Emotional intelligence in front-line/back-office employee relationships}

\begin{tabular}{|r|l|}
\hline Journal: & Journal of Services Marketing \\
\hline Manuscript ID & JSM-09-2016-0339.R1 \\
\hline Manuscript Type: & Article \\
\hline Keywords: & $\begin{array}{l}\text { Emotional intelligence, matched data, moderation, organizational } \\
\text { performance, citizenship behaviours, customer service employees }\end{array}$ \\
\hline \multicolumn{2}{|l}{} \\
\hline
\end{tabular}

SCHOLARONE

Manuscripts 


\section{Emotional intelligence in front-line/back-office employee relationships}

Purpose-This research undertakes a simultaneous assessment of interdependence in the behaviours of front-line and back-office employees and their joint effect on customer-related organizational performance. It also tests for a moderating influence of the emotional intelligence of front-line salespeople and back-office employees.

Design/methodology/approach-The sample comprises 105 front-line sales employees and 77 back-office employees. The customer-related organizational performance data come from a U.K. business-to-business (B2B) electronics company. With these triadic data, this study uses partial least squares to estimate the measurement and structural models.

Findings-Salespeople's customer orientation directly affects customer-related organizational performance; the relationship is moderated by salespeople's emotional intelligence. The emotional intelligence of salespeople also directly affects the customerdirected citizenship behaviour of back-office employees. Furthermore, the emotional intelligence of back-office staff moderates the link between the emotional intelligence of salespeople and back-office staff citizenship behaviour. Back-office staff citizenship behaviour in turn affects customer-related organizational performance.

Originality/value-The emotions deployed by employees in interactions with customers clearly shape customers' perceptions of service quality, as well as employee-level performance outcomes. But prior literature lacks insights into the simultaneous effects of front-line and back-office employee behaviour, especially in B2B settings. This article addresses these research gaps by investigating triadic relationships - among back-office employees, front-line employees and customer outcomes - in a B2B setting, where they are of particular managerial interest.

Keywords - citizenship behaviours, customer service employees, emotional intelligence, matched data, moderation, organizational performance 


\section{Introduction}

In both business-to-consumer (B2C) and business-to-business (B2B) contexts, boundary-spanning, front-line employees such as salespeople personally interact with customers and offer the visible face of the firm (Rupp et al., 2007). In contrast, back-office employees perform functions separate from customers and remain largely invisible to them (Larsson and Bowen, 1989), despite contributing to superior customer experiences (Zomerdijk and Voss, 2010). Customer experience 'refers to the customer's perception of the service operations and processes' (Hakanen and Jaakkola, 2012, p. 597), so it is shaped by the contributions and behaviours of both front-line and back-office employees. For many organizations, effectively aligning boundary-spanning and back-office activities is a necessary prerequisite for successful service delivery and customer satisfaction (Bowen and Schneider, 1985; Gounaris, 2008). Larsson and Bowen (1989, p. 222) even note that frontline employees 'take in the customer's specifications of the service, and it is performed by back-office employees'.

Despite the important, if indirect, contributions of back-office employees to customers' service experience (Zomerdijk and Voss, 2010) and organizational performance, extant service research tends to focus solely on constructs that explain the attitudes and behaviour of front-line employees. Research in the B2C field thus proposes several potential antecedents of organizational performance, such as front-line employees' customer orientation (Brach et al., 2015; Brown et al., 2002; Hennig-Thurau and Thurau, 2003), emotional labour (Groth et al., 2009; Walsh and Bartikowski, 2013) or emotional intelligence (Kidwell et al., 2011; McFarland et al., 2016; Rozell et al., 2004). But constructs from a B2C setting might not extend to B2B professional service settings, where firm-customer relationships differ notably from those involving traditional, consumer end-users. In end-user markets, consumers typically interact with salespeople on a personal, regular basis and spend their own money. 
Conversely, organizational customers and providers often interact indirectly and impersonally, with purchases made with company funds (Von Nordenflycht, 2010; Walsh et al., 2015). Salespeople and their customers might interact less regularly in the B2B field, yet the quality of their relationships often is higher than in B2C settings, such as retailing or fast food (e.g., Mudambi, 2002; Rauyruen and Miller, 2007; Wagner and Boutellier, 2002). In addition, emotions can facilitate these transactions (Andersen and Kumar, 2006), such that B2B firms need emotionally intelligent employees to be able to ensure customer satisfaction and loyalty, as well as ultimate performance outcomes.

Emotional intelligence is 'the ability or tendency to perceive, understand, regulate, and harness emotions adaptively in the self and in others' (Schutte et al., 2001, p. 523). It is positively associated with customer satisfaction, repurchasing intentions, word of mouth (Boxer and Rekettye, 2011; Kernbach and Schutte, 2005) and employee performance (Kidwell et al., 2011; Sy et al., 2006). A wealth of research thus investigates front-line employees' emotional intelligence and relevant downstream variables, though three elements appear missing. First, with a focus on front-line employees and a within-person view, most research considers antecedents or personal consequences of front-line employees' own emotional intelligence, such as how it might drive individual job satisfaction, commitment or performance (Kidwell et al., 2011; McFarland et al., 2016). Such an approach cannot explain the full contribution of salespeople's emotional intelligence to firm outcomes though, given the potential for the reciprocal interpersonal influence of emotional intelligence. A front-line employee's emotional intelligence can create a ripple effect, triggering a flow of emotions to another person that affects that other party's behaviour (Barsade, 2002; Hareli and Rafaeli, 2008; Hennig-Thurau et al., 2006) and thus overall organizational performance. This effect is well acknowledged in employee-customer exchanges (Delcourt et al., 2013) and supervisorsubordinate contexts (McFarland et al., 2016; Sy et al., 2006; Wong and Law, 2002); it rarely 
has been assessed among co-workers. The present research therefore investigates whether front-line employees' emotional intelligence affects the behaviour of their peers who work in the back office.

Second, though front-line employees' emotional intelligence has been linked to relevant downstream variables, such as job satisfaction and emotional labour (e.g., Johnson and Spector, 2007; Prentice et al., 2013), the extent and the manner by which back-office staff's emotional intelligence contributes to organizationally relevant outcomes remains unclear, especially in terms of customer-related organizational performance. Back-office employees’ work may not entail face-to-face contact with customers, but they play a critical role in service delivery; they even might communicate with customers via telephone, e-mail or social media (Korczynski, 2004; Peppard, 2000). Front-line employee emotional intelligence and back-office employee emotional intelligence seemingly might interact to predict outcomes, in a relationship that could be either complementary or substitutive (Chun et al., 2010; Sy et al., 2006). Answering such questions can help highlight whether and how the emotional intelligence of back-office staff contributes to firm outcomes and thus provide guidance for managing both front-line and back-office employees.

Third, various studies note a moderating role of emotional intelligence and provide robust support for direct links between front-line employees' emotional intelligence and employee- and customer-related outcomes (e.g., Kidwell et al., 2011; Nikolaou and Tsaousis, 2002). Yet studies treating emotional intelligence as a moderator tend to ignore organizational performance outcomes. The few studies that include them (e.g., Kidwell et al., 2011; McFarland et al., 2016) ignore non-financial performance metrics and how back-office employees contribute to achieving performance goals. Accordingly, this study measures organizational performance outcomes using key performance indicators (KPIs) that represent 
a set of financial and non-financial measures that are critical to the current and future success of the organization.

In addressing these research gaps, the present research builds on the positive relationship between customer orientation and firm performance (e.g., Jaworski and Kohli, 1993 ) to investigate triadic relationships among front-line employees, back-office employees and customer-related organizational performance, which are of particular managerial concern in B2B markets. In turn, we contribute to theory and literature on emotional intelligence in B2B service settings in three main ways. First, we analyse the influence of the emotional intelligence of front-line employees on the citizenship behaviour of back-office employees. Second, we show that back-office employees' emotional intelligence directly influences the citizenship behaviour of back-office employees and moderates the effect of front-line employees' emotional intelligence on back-office employees' citizenship behaviour. Third, we examine the influence of front-line and back-office employees' emotional intelligence on financial and non-financial performance measures. These issues are important for both practical and theoretical reasons. Practically, this research can strengthen the hands of managers who wish to allocate more resources to develop the emotional intelligence of their customer-contact employees, both on the front line and in the back office. Theoretically, to gain a fuller understanding of the effects of emotional intelligence on organizational outcomes, scholars need to acknowledge the role of back-office employees who have mainly indirect customer contact and move beyond existing bivariate findings to investigate the moderating role of emotional intelligence.

\section{Background and hypotheses}

In the past decade, service research into the moderating role of emotional intelligence has shown (Table 1), for example, that greater emotional intelligence can have a mitigating influence on the links between service employees' negative emotions and emotional 
exhaustion (Szczygieł and Bazińska, 2013), between stress and burnout (Görgens-Ekermans and Brand, 2012) and between emotional labour and burnout (Prentice et al., 2013). Emotional intelligence also influences job-related outcomes, such that Kidwell et al. (2007, 2011) and McFarland et al. (2016) find that emotionally intelligent salespeople effectively apply customer-oriented selling strategies and thereby increase their sales performance. These studies use financial measures or others' performance assessments to measure organizational outcomes, without considering the non-monetary organizational measures, such as customer satisfaction, that are critical to organizational success, in that they predict monetary metrics (Ambler, 2003; Angulo-Ruiz et al., 2014; Katsikeas et al., 2016; Kirca et al., 2005). Therefore, we include both financial and non-financial performance metrics as key outcomes that are measured frequently and acted on by senior management. These metrics also assign responsibility to the individual or team level (Alvandi et al., 2012).

--- insert Table 1 approx. here ---

In terms of emotional intelligence in intra-organizational contexts, front-line employees (i.e., salespeople) have a tremendous influence on the success and failure of business relations. Their personal interaction with customers primarily determines service quality, customer experience and customer satisfaction (e.g., Crosby and Stephens, 1987; Crosby et al., 1990; Hakanen and Jaakkola, 2012; Solomon et al., 1985). Especially in the B2B context, business customers suffer greater uncertainty regarding their purchases of complex goods and services. When selling to business clients, salespeople need profound knowledge of their customers' buying processes and needs, as well as how their company's goods and services can meet them. Thus B2B companies need salespeople who are customer service experts, rather than product experts (Sharma, 2007), and who are primarily customer oriented (Saxe and Weitz, 1982). A customer orientation improves salespeople's performance (e.g., Cross et al., 2007; Dunlap et al., 1988; Jaramillo and Grisaffe, 2009; Rozell et al., 2004; Saxe and 
Weitz, 1982), as well as company performance (e.g., Narver and Slater, 1990; Singh and Ranchhod, 2004). Considering the high quality of the salesperson-customer relationship in B2B contexts (e.g., Mudambi, 2002; Rauyruen and Miller, 2007; Wagner and Boutellier, 2002), we expect front-line employees' customer orientation to have a strong positive influence on the financial and non-financial performance of the organization. H1: The customer orientation of salespeople positively influences organizational performance.

Some studies suggest that emotional intelligence predicts customer orientation (e.g., Rozell et al., 2004), though others treat these constructs as independent (e.g., Kidwell et al., 2011). We consider them separately, because salespeople clearly could exhibit high (low) emotional intelligence and customer orientations or else have high (low) emotional intelligence and a low (high) customer orientation. Salespeople with a stronger customer orientation but low levels of emotional intelligence might try to use their customer orientation to influence customers' decisions, but they might be less effective, due to their inability to incorporate emotional information into the customer interaction. By missing emotional signals and cues, due to their low emotional intelligence, salespeople may end up inducing negative emotions and actions in customers (Groth et al., 2009; Kidwell et al., 2011; Pugh, 2001; Walsh and Bartikowski, 2013). Salespeople with high emotional intelligence and low customer orientation also might produce poor outcomes, because emotional intelligence is morally neutral (Nagler et al., 2014). High levels of emotional intelligence coupled with low levels of customer orientation then might lead salespeople to manipulate customers and act in their own, rather than customers', interests (Nagler et al., 2014). Such a manipulation could lead to short-term gains, but the overall effect likely would involve diminished performance outcomes. In contrast, emotionally intelligent salespeople who are also very customer oriented can better understand and manage their emotions and insert emotional cues (e.g., 
nonverbal gestures, vocal intonations) in the selling process. Their customer-oriented selling thus may be more effective. Accordingly, we hypothesise:

H2: Greater emotional intelligence strengthens the positive influence of salespeople's customer orientation on organizational performance.

The emotional intelligence of one party also can directly influence the behaviours of another. The emotional intelligence of salespeople appears to drive customer loyalty behaviour (Delcourt et al., 2013), and supervisors' emotional intelligence has been directly linked to subordinates' in-role and extra-role behaviour (Wong and Law, 2002), for example. Yet the effect of front-line employees' emotional intelligence on back-office colleagues' emotional intelligence has not received much attention. We therefore turn to the norm of reciprocity (Gouldner, 1960) to argue that the emotional intelligence of salespeople predicts back-office staff citizenship behaviour, which 'is beneficial for an organization but that falls outside of formal role requirements such that it is difficult to formally specify or reward' (Morrison, 1996, p. 493).

Salespeople with high emotional intelligence are better able to respond to the emotions of their back-office colleagues (Greenidge et al., 2014). When back-office colleagues engage or interact with emotionally intelligent salespeople who understand and respond more effectively to their emotions, they should recognize a benefit and feel indebted to these emotionally intelligent salespeople (Blau, 1964). Consequently, back-office employees likely adopt behaviours to restore balance to the relationship. Because citizenship behaviours affect salespeople's performance, a potential way to reciprocate is by engaging in such behaviours. Consequently, we predict:

H3: The emotional intelligence of salespeople positively influences the citizenship behaviour of back-office employees. 
In line with previous studies in this area, we also expect that back-office employees' emotional intelligence directly influences their own citizenship behaviours (Carmeli and Josman, 2006; Ramachandran et al., 2011; Wong and Law, 2002). Emotional intelligence enhances citizenship behaviour by enabling employees to recognize and understand the feelings of those with whom they interact. For example, back-office employees with high levels of emotional intelligence can recognise when salespeople need assistance, which may require the back-office staff to go beyond their normal duties. In addition, back-office employees with more emotional intelligence can perceive customers' emotions effectively and thus manage their emotions and find solutions, which represents a stronger form of customer-oriented citizenship behaviour. Finally, high levels of emotional intelligence mean that back-office employees manage their own emotions better, so they are able to maintain their focus on the customer rather than themselves and more likely to engage in helpful citizenship behaviours (Carmeli and Josman, 2006; Ramachandran et al., 2011).

H4: The emotional intelligence of back-office employees positively influences their citizenship behaviour.

However, the positive effect of salespeople's emotional intelligence on the citizenship behaviour of back-office employees may be moderated by the latter's emotional intelligence. A few studies explore dyadic matches of emotional intelligence between interacting actors and the influences on various outcomes. Some studies suggest a substitution effect, such that the marginal benefit of each variable decreases as the level of the other variable increases (Voss et al., 2010). In their field study, Sy et al. (2006) reveal that managers' emotional intelligence is more strongly associated with job satisfaction among subordinates who have low emotional intelligence. Chun et al. (2010) find, in a mentoring context, that mentors' emotional intelligence relates more strongly to protégés' trust when those protégés' emotional intelligence is low rather than high. 
Despite such findings, we predict a complementary interaction effect (Voss et al., 2010), in that we expect the effect of salespeople's emotional intelligence on back-office employees' citizenship behaviour to increase with the rising level of back-office employees' emotional intelligence. Unlike the previously cited studies, we investigate an interaction of peers' emotional intelligence, which differs from supervisor-subordinate interactions and dynamics. When people receive valued resources through social exchange relationships, they perceive a need to reciprocate (Blau 1964). Therefore, emotionally intelligent back-office employees who realize that salespeople have provided them with emotional resources should engage in similar activities and thus display citizenship behaviours toward customers.

H5: Greater emotional intelligence of back-office employees strengthens the positive influence of the emotional intelligence of salespeople on the citizenship behaviour of the back-office employees.

Employees' customer citizenship behaviours also are critical for organizational success; it is impossible to predict all possible requirements of customers in advance (Bowen et al., 1999). Back-office employees' citizenship behaviour directed toward customers should result in improved organizational performance, because customer-directed citizenship behaviours enhance customer satisfaction (Schneider et al., 2005). More satisfied customers make more repeat visits to the satisfactory firm and increase their purchase levels (Keiningham and Vavra, 2001; Schneider et al., 2005). Because the citizenship behaviour of back-office employees contributes to a superior customer experience, it should improve organizational performance too.

H6: The citizenship behaviour of back-office employees positively influences organizational performance.

--- insert Figure 1 approx. here --- 
Method

With a positivistic perspective, this research uses partial least squares (PLS) to test the hypotheses, which we developed to examine the effects of front-line salespeople's customer orientation and back-office employees' citizenship behaviour on key organizational performance outcomes. In particular, we examine how the emotional intelligence of front-line and back-office employees moderates these key relationships, using quantitative procedures.

\section{Participants and procedures}

The sample consisted of salespeople and back-office employees from a large multinational B2B electronic company in the United Kingdom. This company was suitable for our study: It employs a sizeable workforce, and both front-line and back-office employees come in contact with customers, so we could examine triadic relationships (among front-line employees, back-office employees and their customer-related organizational performance). The company also exhibited strong commitment to the research project and gave the research team full access to its employees and KPI data. The surveys were facilitated with the permission and support of senior management and the IT department. In all, 197 and 295 questionnaires were distributed to salespeople and back-office employees, respectively, across the United Kingdom.

Each participant had an opportunity to participate in a drawing for two $£ 100(\$ 120)$ gift cards. In addition to a pre-notification by company management, we sent two e-mail reminders, one week apart, to increase the response rate. We received responses from 106 salespeople and 77 back-office employees, for response rates of $50.7 \%$ and $26.1 \%$, respectively. Although the back-office employees' response rate was lower, both these rates still compare favourably with previous research using similar samples (e.g., Hancer and George, 2003; Kidwell et al., 2007). Management also noted at the start of the data collection 
that salespeople tended to be more responsive to answering company questionnaires than back-office employees.

To link the 106 salespeople and 77 back-office employees, we asked each participant to identify one member from the opposite group with whom they collaborated most when working on customer orders. This matching process helped us deal with the complex nature of the interactions between salespeople and back-office employees. Management noted that though salespeople deal with many different back-office employees, they consistently rely on a particular customer service centre employee. Most of the back-office employees from whom we collected data belonged to the customer service centre. Usually, each back-office customer service employee works with several salespeople, and similarly, each salesperson needs to interact with several back-office employees. We were able to match 100 salespeople with 74 back-office employees; we then gathered the customer-related KPIs for these 100 salespeople from the company and aligned the KPIs with each salesperson-back-office employee dyad.

Among salespeople, $93 \%$ of the respondents were men, and their average age was 49 years $(S D=.92)$, with an average job tenure in the current organization of 12 years $(S D=$ 1.49). The back-office employees sample consisted of 55\% men. Their average age was 28 years $(S D=1.12)$, and their average length of employment in the current organization was 12 years $(S D=1.53)$.

\section{Measures}

The measurement scales in the questionnaires were either adopted or adapted from previous literature and emphasised the context, in accordance with suggestions from senior management (see the Appendix). The salespeople's customer orientation measure came from Periatt et al.'s (2004) five-item scale, and we adapted the original item 'A good employee has 
to have the customer's best interest in mind' to read, 'A good salesperson has to have the customer's best interest in mind'.

The emotional intelligence measures relied on Wong and Law's (2002) 16-item Emotional Intelligence Scale (WLEIS ), which has been rigorously tested and validated in many industries and cultures (Christie et al., 2007; Libbrecht et al., 2014; Sy et al., 2006). Previous studies (e.g., Kidwell et al., 2011) employ lengthy emotional intelligence measures (e.g., 140 items), but they might cause respondent fatigue, which in turn could adversely affect their reliability. The WLEIS scale instead consists of four items for each of the four dimensions of emotional intelligence. The Self-Emotion Appraisal dimension assesses the self-perceived ability to understand one's own emotions (e.g., 'I have a good sense of why I have certain feelings most of the time'). With the Others' Emotion Appraisal dimension, we assess each person's ability to perceive others' emotions (e.g., 'I am a good observer of others' emotions'). The Regulation of Emotion dimension pertains to the perceived ability to regulate one's own emotions. (e.g., 'I am able to control my temper and handle difficulties rationally'). Finally, with the Use of Emotion dimension, we measure the self-perceived tendency to motivate oneself to enhance performance (e.g., 'I always set goals for myself and then try my best to achieve them'). In line with previous studies (Kafetsios and Zampetakis, 2008; Law et al., 2004), we regard the items as reasonable estimates of the dimensions, so the dimensions in turn can be represented as a multidimensional emotional intelligence construct.

For back-office employees' citizenship behaviour, we used a five-item scale (e.g., 'I voluntary assist the customers even if it means going beyond job requirements') from Bettencourt and Brown (1997). The measure of organizational performance relied on an index based on KPIs provided by the company. The KPIs included both financial (e.g., customer service revenue, product sales revenue, monthly revenue) and non-financial (e.g., 
service excellence, customer feedback, mood indicator) measures. They were unique to each salesperson, so the number of KPIs used in the analysis was substantial. ${ }^{1}$

The measures are self-reported (cf. organizational performance), so we sought to reduce the risk of response biases. First, when administering the questionnaire, we stressed the independence of the research team and the confidentiality of results, especially with regard to internal company usage (i.e., senior managers would not know the identities of respondents). Second, we administered the questionnaire through QUALTRICS, an online survey platform that allowed the employees to complete the survey at their own convenience and, if preferred, outside of work.

Data analysis

To estimate the measurement and structural models, we used PLS, an iterative combination of principal components analysis and ordinary least squares path analysis that serves to maximize the prediction of endogenous constructs (Chin, 1998). The PLS technique offers advantages for accommodating a relatively small sample, because the model parameters are estimated in blocks and do not require an assumption of multivariate normality (Hair et al., 2012). Furthermore, PLS does not lead to estimation problems such as improper or non-convergent results, so it can handle complex models, such as those that include moderator variables (Hair et al., 2014). To test the moderating hypotheses, we adopted a product indicator approach (Chin et al., 2003). Following the procedure proposed by Henseler and Chin (2010), the indicators of the main and moderating variables were first standardized by mean-centring, which facilitates the interpretation of the interaction model results. Then we created pairwise product indicators by multiplying each indicator of the main construct with each indicator of the moderating construct. Finally, the product indicators provided the interaction construct. The bootstrapping procedure used 1,000

\footnotetext{
${ }^{1}$ The full list of KPIs included in this study is available on request.
} 
resamples in SmartPLS software, and it generated robust standard errors and t-statistics (Hair et al., 2014).

\section{Results}

The composite reliabilities for all variables exceed the cut-off value of .80, the average variance extracted (AVE) values for all focal variables exceed .50, and all indicators load significantly $(p<.05)$ and substantially $(>.70)$ on their hypothesized factors, so each construct has acceptable convergent validity (Fornell and Larcker, 1981). The square root of the AVE for each construct also exceeds its correlations with other model constructs (see Table 2), in support of discriminant validity (Fornell and Larcker, 1981). In addition, the cross-loadings are not substantial compared with the loadings on the hypothesized factors, thus providing additional support of discriminant validity (Hair et al., 2014).

--- Insert Table 2 approx. here ---

The percentages of explained variance $\left(R^{2}\right)$ for back-office employees' citizenship behaviour and organizational performance are .41 and .04 respectively, indicating the acceptable explanatory power of the model (Hair et al., 2014). Table 3 provides a summary of the results.

--- Insert Table 3 approx. here ---

\section{Main and moderating effects}

We predicted in H1 that salespeople's customer orientation is positively associated with organizational performance, and our analysis confirms this hypothesis $(\beta=.18, p<.05)$. In addition, $\mathrm{H} 2$ proposes that salespeople's emotional intelligence strengthens the positive effect of salespeople's customer orientation on organizational performance, which is supported by the data $(\beta=.21, p<.05)$. Consistent with H3, salespeople's emotional intelligence is positively associated with back-office employees' citizenship behaviour $(\beta=.29, p<.05)$. In H4, we predicted that back-office employees' emotional intelligence is positively associated 
with back-office employees' citizenship behaviour, and our analysis confirms this hypothesis $(\beta=.31, p<.05)$. As we anticipated in H5, back-office employees' emotional intelligence accentuates the positive effects of salespeople's emotional intelligence on back-office employees' citizenship behaviour, with a significant interaction term $(\beta=.17, p<.05)$ that confirms the moderating role of back-office employees' emotional intelligence. Finally, in support of H6, back-office employees' citizenship behaviour is positively associated with organizational performance $(\beta=.32, p<.05)$.

\section{Post hoc analysis}

We included covariates related to the salespeople and back-office employees to test the robustness of the hypothesized relationships. We controlled for gender, age, job tenure, type of role, amount of direct customer contact and sales experience. Their inclusion did not alter the substantive findings in any way, indicating the absence of an omitted variable bias (Becker et al., 2016). These results thus affirm the robustness of our findings.

\section{Discussion}

Past research appears premised on the idea that front-line employees (i.e., salespeople) have, and need, higher levels of emotional intelligence than do back-office employees, because the latter are largely shielded from or only have indirect contact with customers (e.g., Dimitriades, 2007). We regard this assumption as inaccurate. Especially as companies increasingly embrace customer relationship management (CRM) and seek to address all aspects of a holistic customer experience (Ernst et al., 2011), all employees need to contribute to enhanced customer relationships. From a CRM perspective, back-office employees are imperative to building and nurturing customer relationships. Therefore, backoffice employees must be customer-centric and exhibit emotional intelligence.

With this study, we examine the links between front-line employees' customer orientation and customer-related organizational performance, as well as the links between 
their emotional intelligence and the customer-directed citizenship behaviour of back-office employees, which in turn can influence organizational performance. In addition, we examine the boundary conditions of the links between front-line employees' customer orientation and organizational performance and between front-line employees' emotional intelligence and back-office employees' citizenship behaviour. Drawing on a review of the pertinent literature and an empirical study, we find support for the moderating role of front-line employees' and back-office employees' emotional intelligence. Specifically, salespeople's emotional intelligence enhances the positive effect of their customer orientation on organizational performance; back-office employees' emotional intelligence also strengthens the positive effect of salespeople's emotional intelligence on back-office employees' citizenship behaviour, which in turn has a positive influence on organizational performance. Our research builds on and extends research that has focussed on the direct relationships between front-line employees' emotional intelligence and customer or organizational outcomes (e.g., Chen and Jaramillo, 2014; Görgens-Ekermans and Brand, 2012) by considering back-office employees, as well as the contingencies of their important relationships.

\section{Theoretical implications}

Emotional intelligence theory highlights the importance of desirable employee behaviours resulting from emotional intelligence, such as job satisfaction (Sy et al., 2006), as well as the moderating role of emotional intelligence (McFarland et al., 2016). However, prior research mostly notes the effect of front-line employees' emotional intelligence on financial performance measures (Kidwell et al., 2007, 2011; McFarland et al., 2016). Such an isolated view ignores the vast complexity of most companies' organizational structures. Front-line employees often must interact with not only customers but also peers who help them process the customer transactions. To advance emotional intelligence theory, we consider both front-line and back-office employees, as well as some boundary conditions of 
their important relationships. The resulting, more comprehensive view of working relationships in $\mathrm{B} 2 \mathrm{~B}$ companies and their influence on customer-related organizational performance extends theory in three main directions.

First, we acknowledge and empirically corroborate the existence of patterns of interdependence between front-line and back-office employees. Specifically, we extend emotional intelligence theory by showing that front-line employees' emotional intelligence drives customer-related organizational performance by influencing front-line employees' behaviour and also by exerting an effect on the behaviour of back-office co-workers. Second, we show that back-office employees' emotional intelligence influences customer-related organizational performance by increasing customer-directed citizenship behaviours and strengthening the effect of salespeople's emotional intelligence on back-office employees' citizenship behaviour. Third, we find that front-line and back-office employees' behaviour and their emotional intelligence affect KPIs, including both financial and non-financial performance metrics of $\mathrm{B} 2 \mathrm{~B}$ companies that are critical to organizational success, because they predict financial performance metrics.

\section{Managerial implications}

From a managerial perspective, our findings suggest that all employees who come in contact with customers need to be considered when devising strategies for increasing customer-related organizational performance. Companies should not limit their resources and support to salespeople on the front line; instead, they need to equip employees with necessary emotional skills at all points of contact with customers. Considering the direct and moderating effects of emotional intelligence on key outcomes, we recommend that all customer-contact employees receive training to increase their emotional competence. Toward this end, companies could launch emotional intelligence training programmes (Furnham, 
2009), in line with evidence that shows that such programmes are effective at increasing both the emotional intelligence and the sales performance of salespeople (Gignac et al., 2012).

Our findings also provide clear indications for customer-centric companies that view recruitment as a strategic activity. When hiring new employees, they should screen to select for emotional intelligence as a key competence. Companies could issue an emotional intelligence test and thereby exclude candidates who are poorly suited to customer contact jobs (cf. Austin et al., 2004). Using such tests early in the selection process is advisable, because it prevents unsuitable candidates from going through to the more difficult, expensive stages of the recruitment process (Bateson et al., 2014). Such efficient, inexpensive tests can help ensure that the selected candidates possess emotional intelligence and are able to perform well in relation to customers and fellow employees, as well as across various performance dimensions.

In addition to training to all employees that contribute to the service experience, companies could leverage their existing employees with high emotional intelligence as internal coaches. Bande et al. (2015) report that salespeople with high emotional intelligence are less likely to experience emotional exhaustion or quit as a result of it. Therefore, emotionally intelligent salespeople tend to stay with the organization longer than those with lower emotional intelligence. Companies could pair such emotionally intelligent employees with less emotionally intelligent performers, to help the latter learn the ins and outs of emotional intelligence, especially in relation to customers.

\section{Limitations and further research}

Our study is not free of limitations, which in turn offer opportunities for research. We purposefully gathered data from one B2B company, to ensure high internal validity, but in doing so, we sacrificed some external validity. Additional research could examine the replicability of our results in a field study with a cross-section of B2B firms. We also were 
unable to measure other employee outcomes, such as job satisfaction or organizational identification. In designing the questionnaires, we sought comments from senior managers of the focal organization regarding the length of time that respondents might be willing to spend completing the questionnaire. We accordingly avoided an overly long questionnaire, out of concerns that it might detrimentally affect the response rate. Further research into the emotional intelligence of front-line and back-office employees might adopt a nomological model and include more employee outcomes.

We also note the need to link employee emotional intelligence with customer emotional intelligence. The present study is premised on the assumption that employee emotional intelligence (at the front line and in the back office) positively affects customer attitudes and drives customer-related organizational outcomes. We did not demonstrate this link empirically though. Further studies might use dyadic data and thereby link emotional intelligence at the individual employee level to the customer level. Another option is that customers who score high on emotional intelligence are less receptive to the emotional intelligence of employees; in such cases, employee emotional intelligence might have weaker effects on organizational outcomes. We hope additional studies address these possibilities. 


\section{References}

Alvandi, M., Fazil, S., Yazdani, L. and Aghaee, M. (2012), "An integrated MCDM method in ranking BSC perspectives and key performance indicators (KPIs)", Management Science Letters, Vol. 2 No. 3, pp. 995-1004.

Ambler, T. (2003), Marketing and the bottom line: the marketing metrics to pump up cash flow. Pearson Education, Harlow.

Andersen, P.H. and Kumar, R. (2006), "Emotions, trust and relationship development in business relationships: A conceptual model for buyer-seller dyads", Industrial Marketing Management, Vol. 35 No. 4, pp. 522-535.

Angulo-Ruiz, F., Donthu, N., Prior, D. and Rialp, J. (2014), "The financial contribution of customer-oriented marketing capability", Journal of the Academy of Marketing Science, Vol. 42 No. 4, pp. 380-399.

Austin, E.J., Saklofske, D.H., Huang, S.H. and McKenney, D. (2004), "Measurement of trait emotional intelligence: Testing and cross-validating a modified version of Schutte et al.'s (1998) measure", Personality and Individual Differences, Vol. 36 No. 3, pp. 555-562.

Bande, B., Fernández-Ferrín, P., Varela, J.A. and Jaramillo, F. (2015), "Emotions and salesperson propensity to leave: The effects of emotional intelligence and resilience", Industrial Marketing Management, Vol. 44, pp. 142-153.

Barsade, S.G. (2002), "The ripple effect: Emotional contagion and its influence on group behaviour", Administrative Science Quarterly, Vol. 47 No. 4, pp. 644-675.

Bateson, J.E.G., Wirtz, J., Burke, E. and Vaughan, C. (2014), "Psychometric sifting to efficiently select the right service employees", Managing Service Quality, Vol. 24 No. 5, pp. 418-433.

Becker, T.E., Atinc, G, Breaugh, J.A., Carlson, K.D., Edwards, J.R. and Spector, P.E. (2016), "Statistical control in correlational studies: 10 essential recommendations for organizational researchers", Journal of Organizational Behavior, Vol. 37 No. 2, pp. 157167.

Bettencourt, L.A. and Brown, S.W. (1997), "Contact employees: Relationships among workplace fairness, job satisfaction and prosocial service behaviors", Journal of Retailing, Vol. 73 No. 1, pp. 39-61.

Bibi, Z., Karim, J. and Ud Din, S. (2013), "Workplace Incivility and Counterproductive Work Behavior: Moderating Role of Emotional Intelligence", Pakistan Journal of Psychological Research, Vol. 28 No. 2, pp. 317-334.

Blau, P.M. (1964), Exchange and power in social life, Transaction Publishers, New Brunswick, New Jersey.

Bowen, D.E., Gilliland, S.W. and Folger, R. (1999), "HRM and service fairness: how being fair with employees spills over to customers", Organizational Dynamics, Vol. 27, pp. 723.

Bowen, D.E. and Schneider, B. (1985), "Boundary-spanning Role Employees and the Service Encounter: Some Guidelines for Management and Research”, in Czepiel, J.A., Solomon, M.R., and Surprenant, C.F. (Ed.), The Service Encounter, Lexington Books, Lexington, MA, pp. 127-47.

Boxer, I. and Rekettye, G. (2011), "The relation between perceived service innovation, service value, emotional intelligence, customer commitment and loyalty in b2b", International Journal of Services and Operations Management, Vol. 8 No. 2, pp. 222256.

Brach, S., Walsh, G., Hennig-Thurau, T. and Groth, M. (2015), “A Dyadic Model of Customer Orientation: Mediation and Moderation Effects", British Journal of Management, Vol. 26 No. 2, pp. 292-309. 
Brown, T.J., Mowen, J.C., Donavan, D.T. and Licata, J.W. (2002), "The customer orientation of service workers: Personality trait effects on self-and supervisor performance ratings", Journal of Marketing Research, Vol. 39 No. 1, pp. 110-119.

Carmeli, A. and Josman, Z.E. (2006), "The relationship among emotional intelligence, task performance, and organizational citizenship behaviors", Human performance, Vol. 19 No. 4, pp. 403-419.

Chen, C.-C. and Jaramillo, F. (2014), "The double-edged effects of emotional intelligence on the adaptive selling-salesperson-owned loyalty relationship", Journal of Personal Selling \& Sales Management, Vol. 34 No. 1, pp. 33-50.

Chin, W.W. (1998), "The partial least squares approach to structural equation modelling", in Marcoulides, G.A. (Ed.), Modern methods for business research, Lawrence Erlbaum Associates, Mahwah, NJ, pp. 295-336.

Chin, W.W., Marcolin, B.L. and Newsted, P.R. (2003), "A partial least squares latent variable modeling approach for measuring interaction effects: Results from a Monte Carlo simulation study and voice mail emotion/adoption study", Information Systems Research, Vol. 14 No. 2, pp. 189-217.

Christie, A., Jordan, P., Troth, A. and Lawrence, S. (2007), “Testing the Links Between Emotional Intelligence and Motivation”, Journal of Management \& Organization, Vol. 13 No. 3, pp. 212-226.

Chun, J.U., Litzky, B.E., Sosik, J. J., Bechtold, D.C., and Godshalk, V.M. (2010), “Emotional intelligence and trust in formal mentoring programs", Group \& Organization Management, Vol. 35 No. 4, pp. 421-455.

Crosby, L.A., Evans, K.R. and Cowles, D. (1990), "Relationship quality in services selling: an interpersonal influence perspective", Journal of Marketing, Vol. 54 No. 3, pp. 68-81.

Crosby, L.A. and Stephens, N. (1987), "Effects of relationship marketing on satisfaction, retention, and prices in the life insurance industry", Journal of Marketing Research, Vol. 24 No. 4, pp. 404-411.

Cross, M.E., Brashear, T.G., Rigdon, E.E. and Bellenger, D.N. (2007), "Customer orientation and salesperson performance", European Journal of Marketing, Vol. 41 No. 7/8, pp. 821-835.

Delcourt, C., Gremler, D. D., van Riel, A. C., and van Birgelen, M. (2013), "Effects of perceived employee emotional competence on customer satisfaction and loyalty: The mediating role of rapport", Journal of Service Management, Vol. 24 No. 1, pp. 5-24.

Devonish, D. and Greenidge, D. (2010), "The Effect of Organizational Justice on Contextual Performance, Counterproductive Work Behaviors, and Task Performance: Investigating the moderating role of ability-based emotional intelligence", International Journal of Selection \& Assessment, Vol. 18 No. 1, pp. 75-86.

Dimitriades, Z.S. (2007), "Managing emotionally intelligent service workers: Personal and positional effects in the Greek context", Journal of European Industrial Training, Vol. 31 No. 3, pp. 223-240.

Dunlap, B.J., Dotson, M.J. and Chambers, T.M. (1988), "Perceptions of real-estate brokers and buyers: A sales-orientation, customer-orientation approach", Journal of Business Research, Vol. 17 No. 2, pp. 175-187.

Ernst, H., Hoyer, W.D., Krafft, M. and Krieger, K. (2011), “Customer relationship management and company performance - the mediating role of new product performance", Journal of the Academy of Marketing Science, Vol. 39 No. 2, pp. 290-306.

Fornell, C. and Larcker, D. (1981), "Evaluating Structural Equation Models with Unobservable Variables and Measurement Error", Journal of Marketing Research, Vol. 18 No. 1 , pp. 39-50. 
Furnham, A. (2009), "The importance and training of emotional intelligence at work", In C. Stough, D. H. Saklofske, and J. D. A. Parker (Eds.), Assessing emotional intelligence: Theory, research and applications (pp. 137-155). New York, NY: Springer Science + Business Media.

Gao, Y., Shi, J., Niu, Q. and Wang, L. (2013), "Work-Family Conflict and Job Satisfaction: Emotional Intelligence as a Moderator", Stress \& Health: Journal of the International Society for the Investigation of Stress, Vol. 29 No. 3, pp. 222-228.

Gignac, G.E., Harmer, R.J., Jennings, S. and Palmer, B.R. (2012), "EI training and sales performance during a corporate merger", Cross Cultural Management: An International Journal, Vol. 19 No. 1, pp. 104-116.

Görgens-Ekermans, G. and Brand, T. (2012), "Emotional intelligence as a moderator in the stress-burnout relationship: a questionnaire study on nurses", Journal of Clinical Nursing, Vol. 21 No. 15/16, pp. 2275-2285.

Gouldner, A.W. (1960), "The norm of reciprocity: a preliminary statement", American Sociological Review of General Psychology, Vol. 25 No. 2, pp. 161-78

Gounaris, S. (2008), "The notion of internal market orientation and employee job satisfaction: some preliminary evidence", Journal of Services Marketing, Vol. 22 No. 1, pp. 68-90.

Greenidge, D., Devonish, D. and Alleyne, P. (2014), “The Relationship Between AbilityBased Emotional Intelligence and Contextual Performance and Counterproductive Work Behaviors: A Test of the Mediating Effects of Job Satisfaction”, Human Performance, Vol. 27 No. 3, pp. 225-242.

Groth, M., Hennig-Thurau, T. and Walsh, G. (2009), "Customer reactions to emotional labor: The roles of employee acting strategies and customer detection accuracy", Academy of Management Journal, Vol. 52 No. 5, pp. 958-974.

Hair, J.F., Hult, G.T.M., Ringle, C.M. and Sarstedt, M. (2014), A Primer on Partial Least Squares Structural Equation Modeling (PLS-SEM), SAGE Publications, Thousand Oaks, CA.

Hair, J.F., Sarstedt, M., Ringle, C.M. and Mena, J.A. (2012), "An assessment of the use of partial least squares structural equation modeling in marketing research", Journal of the Academy of Marketing Science, Vol. 40 No. 3, pp. 414-433.

Hakanen, T. and Jaakkola, E. (2012), "Co-creating customer-focused solutions within business networks: a service perspective", Journal of Service Management, Vol. 23 No. 4, pp. 593-611.

Hancer, M. and George, R.T. (2003), "Psychological empowerment of non-supervisory employees working in full-service restaurants", International Journal of Hospitality Management, Vol. 22 No. 1, pp. 3-16.

Hareli, S. and Rafaeli, A. (2008), "Emotion cycles: On the social influence of emotion in organizations", Research in Organizational Behavior, Vol. 28, pp. 35-59.

Hennig-Thurau, T., Groth, M., Paul, M. and Gremler, D. (2006), "Are All Smiles Created Equal? How Emotional Contagion and Emotional Labor Affect Service Relationships", Journal of Marketing, Vol. 70 No. 3, pp. 58-73.

Hennig-Thurau, T. and Thurau, C. (2003), "Customer orientation of service employeesToward a conceptual framework of a key relationship marketing construct", Journal of Relationship Marketing, Vol. 2 No. 1/2, pp. 23-41.

Henseler, J. and Chin, W.W. (2010), “A comparison of approaches for the analysis of interaction effects between latent variables using partial least squares path modeling", Structural Equation Modeling, Vol. 17 No. 1, pp. 82-109. 
Jaramillo, F. and Grisaffe, D.B. (2009), "Does customer orientation impact objective sales performance? Insights from a longitudinal model in direct selling", Journal of Personal Selling \& Sales Management, Vol. 29 No. 2, pp. 167-178.

Jaworski, B.J. and Kohli, A.K. (1993), "Market orientation: antecedents and consequences", Journal of Marketing, Vol. 57 No. 3, pp. 53-70.

Johnson, H.-A.M. and Spector, P.E. (2007), "Service with a smile: Do emotional intelligence, gender, and autonomy moderate the emotional labor process?", Journal of Occupational Health Psychology, Vol. 12 No. 4, pp. 319-333.

Kafetsios, K. and Zampetakis, L.A. (2008), "Emotional intelligence and job satisfaction: Testing the mediatory role of positive and negative affect at work", Personality and Individual Differences, Vol. 44 No. 3, pp. 712-722.

Katsikeas, C. S., Morgan, N. A., Leonidou, L. C., and Hult, G. T. M. (2016), “Assessing performance outcomes in marketing", Journal of Marketing, Vol. 80 No. 2, pp. 1-20.

Keiningham, T.L. and Vavra, T.G. (2001), The customer delight principle: Exceeding customers' expectations for bottom-line success, McGraw-Hill, New York.

Kernbach, S. and Schutte, N.S. (2005), "The impact of service provider emotional intelligence on customer satisfaction", Journal of Services Marketing, Vol. 19 No. 7, pp. 438-444.

Kidwell, B., Hardesty, D.M., Murtha, B.R. and Sheng, S. (2011), "Emotional intelligence in marketing exchanges", Journal of Marketing, Vol. 75 No. 1, pp. 78-95.

Kidwell, B., McFarland, R.G. and Avila, R.A. (2007), "Perceiving emotion in the buyerseller interchange: the moderated impact on performance", Journal of Personal Selling \& Sales Management, Vol. 27 No. 2, pp. 119-132.

Kirca, A. H., Jayachandran, S. and Bearden, W. O. (2005), "Market orientation: A metaanalytic review and assessment of its antecedents and impact on performance", Journal of Marketing, Vol. 69 No. 2, pp. 24-41.

Korczynski, M. (2004), "Back-office service work: bureaucracy challenged?”, Work, Employment \& Society, Vol. 18 No. 1, pp. 97-114.

Larsson, R. and Bowen, D.E. (1989), "Organization and customer: managing design and coordination of services", Academy of Management Review, Vol. 14 No. 2, pp. 213-233.

Law, K.S., Chi-Sum, W. and Song, L.J. (2004), "The Construct and Criterion Validity of Emotional Intelligence and Its Potential Utility for Management Studies", Journal of Applied Psychology, Vol. 89 No. 3, pp. 483-496.

Libbrecht, N., Beuckelaer, A.D., Lievens, F. and Rockstuhl, T. (2014), "Measurement Invariance of the Wong and Law Emotional Intelligence Scale Scores: Does the Measurement Structure Hold across Far Eastern and European Countries?", Applied Psychology: An International Review, Vol. 63 No. 2, pp. 223-237.

McFarland, R.G., Rode, J.C. and Shervani, T.A. (2016), "A contingency model of emotional intelligence in professional selling", Journal of the Academy of Marketing Science, Vol. 44 No. 1, pp. 108-118.

Morrison, E.W. (1996), "Organizational citizenship behavior as a critical link between HRM practices and service quality", Human Resource Management (1986-1998), Vol. 35 No. 4, pp. 493-512.

Mudambi, S. (2002), "Branding importance in business-to-business markets: Three buyer clusters", Industrial Marketing Management, Vol. 31 No. 6, pp. 525-533.

Nagler, U. K., Reiter, K. J., Furtner, M. R., and Rauthmann, J. F. (2014), "Is there a "dark intelligence"? Emotional intelligence is used by dark personalities to emotionally manipulate others", Personality and Individual Differences, Vol. 65, pp. 47-52.

Narver, J.C. and Slater, S.F. (1990), "The effect of a market orientation on business profitability", Journal of Marketing, Vol. 54 No. 4, pp. 20-35. 
Nikolaou, I. and Tsaousis, I. (2002), "Emotional intelligence in the workplace: Exploring its effects on occupational stress and organizational commitment", The International Journal of Organizational Analysis, Vol. 10 No. 4, pp. 327-342.

Ojedokun, O. (2010), "Effort-reward imbalance and attitude towards unethical work behaviour among police personnel: Emotional intelligence as a moderator", IFE Psychologia: An International Journal, Vol. 18 No. 1, pp. 168-189.

Palmer, B. and C. Stough (2001), "Workplace SUEIT: Swinburne University Emotional Intelligence Test-Descriptive Report," Organisational Psychology Research Unit, Swinburne University, AU.

Peppard, J. (2000), "Customer relationship management (CRM) in financial services", European Management Journal, Vol. 18 No. 3, pp. 312-327.

Periatt, J.A., LeMay, S.A. and Chakrabarty, S. (2004), "The selling orientation-customer orientation (SOCO) scale: Cross-validation of the revised version", Journal of Personal Selling \& Sales Management, Vol. 24 No.1, pp. 49-54.

Prentice, C., Chen, P.-J. and King, B. (2013), "Employee performance outcomes and burnout following the presentation-of-self in customer-service contexts", International Journal of Hospitality Management, Vol. 35, pp. 225-236.

Pugh, S.D. (2001), "Service with a smile: Emotional contagion in the service encounter", Academy of Management Journal, Vol. 44 No. 5, pp. 1018-1027.

Qazi, T.F., Shafique, M. and Ahmad, R. (2014), "Unveiling Leadership-Employee Performance Links: Perspective of Young Employees”, Pakistan Journal of Statistics \& Operation Research, Vol. 10 No. 4, pp. 467-473.

Ramachandran, Y., Jordan, P.J., Troth, A.C. and Lawrence, S.A. (2011), "Emotional intelligence, emotional labour and organisational citizenship behaviour in service environments", International Journal of Work Organisation and Emotion, Vol. 4 No. 2, pp. 136-157.

Rauyruen, P. and Miller, K. E. (2007), "Relationship quality as a predictor of B2B customer loyalty", Journal of Business Research, Vol. 60 No. 1, pp. 21-31.

Rozell, E.J., Pettijohn, C.E. and Parker, R.S. (2004), "Customer-oriented selling: exploring the roles of emotional intelligence and organizational commitment", Psychology \& Marketing, Vol. 21 No. 6, pp. 405-424.

Rupp, D.E., McCance, A.S. and Grandey, A. (2007), “A cognitive-emotional theory of customer injustice and emotional labor", Advances in the Psychology of Justice and Affect, pp. 199-226.

Salovey, P. and Mayer, J.D. (1990), "Emotional intelligence”, Imagination, Cognition and Personality, Vol. 9 No. 3, pp. 185-211.

Saxe, R. and Weitz, B.A. (1982), "The SOCO scale: A measure of the customer orientation of salespeople", Journal of Marketing Research, Vol. 19 No. 3, pp. 343-351.

Schneider, B., Ehrhart, M.G., Mayer, D.M., Saltz, J.L. and Niles-Jolly, K. (2005), "Understanding organization-customer links in service settings", Academy of Management Journal, Vol. 48 No. 6, pp. 1017-1032.

Schutte, N.S., Malouff, J.M., Bobik, C., Coston, T.D., Greeson, C., Jedlicka, C., Rhodes, E. and Wendorf, G. (2001), "Emotional intelligence and interpersonal relations", The Journal of social psychology, Vol. 141 No. 4, pp. 523-536.

Schutte, N.S., Malouff, J.M., Hall, L.E., Haggerty, D.J., Cooper, J.T., Golden, C.J. and Dornheim, L. (1998), "Development and validation of a measure of emotional intelligence", Personality and individual differences, Vol. 25 No. 2, pp. 167-177.

Sharma, A. (2007), "The shift in sales organizations in business-to-business services markets", Journal of Services Marketing, Vol. 21 No. 5, pp. 326-333. 
Singh, S. and Ranchhod, A. (2004), "Market orientation and customer satisfaction: Evidence from British machine tool industry", Industrial Marketing Management, Vol. 33 No. 2, pp. 135-144.

Solomon, M.R., Surprenant, C., Czepiel, J.A. and Gutman, E.G. (1985), “A role theory perspective on dyadic interactions: the service encounter", Journal of Marketing, Vol. 49 No. 1, pp. 99-111.

Sy, T., Tram, S. and O’Hara, L.A. (2006), "Relation of employee and manager emotional intelligence to job satisfaction and performance", Journal of Vocational Behavior, Vol. 68 No. 3, pp. 461-473.

Szczygieł, D. and Bazińska, R. (2013), "Emotional intelligence as a moderator in the relationship between negative emotions and emotional exhaustion among employees in service sector occupations", Polish Psychological Bulletin, Vol. 44 No. 2, pp. 201-212.

Vigoda-Gadot, E. and Meisler, G. (2010), "Emotions in Management and the Management of Emotions: The Impact of Emotional Intelligence and Organizational Politics on Public Sector Employees", Public Administration Review, Vol. 70 No. 1, pp. 72-86.

Von Nordenflycht, A. (2010), "What is a professional service firm? Toward a theory and taxonomy of knowledge-intensive firms", Academy of Management Review, Vol. 35 No. 1, pp. 155-74.

Voss, G. B., Godfrey, A. and Seiders, K. (2010), "How complementarity and substitution alter the customer satisfaction-repurchase link", Journal of Marketing, Vol. 74 No. 6, pp. 111-127.

Wagner, S. M. and Boutellier, R. (2002), "Capabilities for managing a portfolio of supplier relationships”, Business Horizons, Vol. 45 No. 6, pp. 79-88.

Walsh, G. and Bartikowski, B. (2013), "Employee emotional labour and quitting intentions: moderating effects of gender and age", European Journal of Marketing, Vol. 47 No. 8, pp. 1213-1237.

Walsh, G., Beatty, S.E. and Holloway, B.B. (2015), "Measuring client-based corporate reputation in B2B professional services: scale development and validation", Journal of Services Marketing, Vol. 29 No. 3, pp. 173-187.

Wong, C.S. and Law, K.S. (2002), "The effects of leader and follower emotional intelligence on performance and attitude: An exploratory study", The Leadership Quarterly, Vol. 13 No. 3, pp. 243-274.

Zomerdijk, L.G. and Voss, C.A. (2010), "Service design for experience-centric services", Journal of Service Research, Vol. 13 No. 1, pp. 67-82. 
Table 1 Literature synthesis (2006-2016)

\begin{tabular}{|c|c|c|c|c|c|c|}
\hline Author(s) & Sample & Relationship & $\begin{array}{l}\text { Theoretical Frameworks: } \\
\text { Scales }\end{array}$ & Analysis: Findings & \multicolumn{2}{|c|}{$\begin{array}{l}\text { Mediator(s) Moderator(s) } \\
\text { Considered Considered }\end{array}$} \\
\hline $\begin{array}{l}\text { McFarland et al. } \\
\text { (2016) }\end{array}$ & $\begin{array}{l}\mathrm{N}=143 \\
\text { salespeople, } \mathrm{N}= \\
33 \text { supervisors, } \\
3 \text { matched data } \\
\text { sources* }\end{array}$ & $\begin{array}{l}\text { Salespeople's } \\
\text { sales } \\
\text { performance }\end{array}$ & $\begin{array}{l}\text { Appraisal theory, } \\
\text { contingency theory, and } \\
\text { role stress: MSCEIT** }\end{array}$ & $\begin{array}{l}\text { HLM: EI moderates the relationship of role } \\
\text { ambiguity with emotional exhaustion, customer- } \\
\text { oriented selling and sales performance }\end{array}$ & None & EI \\
\hline Qazi et al. (2014) & $\begin{array}{l}\mathrm{N}=100 \text { telecom } \\
\text { and banking }\end{array}$ & N/A & $\begin{array}{l}\text { EI: Does not say which } \\
\text { scale used. }\end{array}$ & $\begin{array}{l}\text { Regression: EI of employees has no moderating } \\
\text { effect on the leadership-performance relationship. }\end{array}$ & None & EI \\
\hline Bibi et al. (2013) & $\begin{array}{l}\mathrm{N}=160 \text { lectures at } \\
7 \text { private } \\
\text { universities }\end{array}$ & N/A & EI: WLEIS** & $\begin{array}{l}\text { Hierarchical regression analyses: EI moderates the } \\
\text { relationship between workplace incivility and } \\
\text { counterproductive work behaviour }\end{array}$ & None & EI \\
\hline Gao et al. (2013) & $\begin{array}{l}\mathrm{N}=212 \text { school } \\
\text { teachers }\end{array}$ & $\mathrm{N} / \mathrm{A}$ & $\begin{array}{l}\text { Conservation of resource } \\
\text { theory: WLEIS** }\end{array}$ & $\begin{array}{l}\text { Hierarchical multiple regression analyses: EI } \\
\text { moderates the relationship between work-family } \\
\text { conflict and job satisfaction }\end{array}$ & None & EI \\
\hline $\begin{array}{l}\text { Prentice et al. } \\
\text { (2013) }\end{array}$ & $\begin{array}{l}\mathrm{N}=578 \text { hospitality } \\
\text { organizations }\end{array}$ & N/A & EI: EIS** & $\begin{array}{l}\text { Structural equation modelling: EI moderates the } \\
\text { relationship between emotional labour and burnout }\end{array}$ & None & $\begin{array}{l}\text { EI, } \\
\text { organizational } \\
\text { commitment }\end{array}$ \\
\hline $\begin{array}{l}\text { Szczygieł and } \\
\text { Bazińska (2013) }\end{array}$ & $\begin{array}{l}\mathrm{N}=137 \text { service } \\
\text { sector employees }\end{array}$ & $\mathrm{N} / \mathrm{A}$ & $\begin{array}{l}\text { EI: Trait EI } \\
\text { Questionnaire-Short } \\
\text { Form (TEIQue-SF) }\end{array}$ & $\begin{array}{l}\text { Hierarchical multiple regression analysis: EI } \\
\text { moderates the relationship between negative } \\
\text { emotions and emotional exhaustion }\end{array}$ & $\begin{array}{l}\text { Negative } \\
\text { emotions }\end{array}$ & EI \\
\hline $\begin{array}{l}\text { Görgens- } \\
\text { Ekermans and } \\
\text { Brand (2012) }\end{array}$ & $\begin{array}{l}\mathrm{N}=122 \text { nurses in } \\
4 \text { hospitals }\end{array}$ & N/A & $\begin{array}{l}\text { EI: } 64 \text { item self-report, } \\
\text { Swinburne University EI } \\
\text { test (Palmer and Stough } \\
\text { 2001) }\end{array}$ & $\begin{array}{l}\text { Multiple regression: The moderator effect of EI in } \\
\text { the stress-burnout relationship suggests that } \\
\text { enhanced EI may help diminish burnout. }\end{array}$ & None & EI \\
\hline $\begin{array}{l}\text { Kidwell et al. } \\
\text { (2011) }\end{array}$ & $\begin{array}{l}\text { Study } 1: N=69 \\
\text { Study } 2: N=107 \\
\text { Study } 3: N=88 \\
\text { Salespeople, B2C }\end{array}$ & $\begin{array}{l}\text { Salespeople's } \\
\text { sales } \\
\text { performance }\end{array}$ & $\begin{array}{l}\text { Customer orientation: } \\
\text { MSCEIT and EI Measure } \\
\text { (EIME) }\end{array}$ & $\begin{array}{l}\text { Sales professionals with higher EI are not only } \\
\text { superior revenue generators but also better at } \\
\text { retaining customers. EI moderates the relationship } \\
\text { between customer orientation and sales performance }\end{array}$ & EI & EI \\
\hline $\begin{array}{l}\text { Devonish and } \\
\text { Greenidge } \\
(2010)\end{array}$ & $\begin{array}{l}\mathrm{N}=211 \text { financial, } \\
\text { manufacturing, } \\
\text { services, private \& } \\
\text { public sector }\end{array}$ & N/A & EI: WLEIS** & $\begin{array}{l}\text { Hierarchical moderated regression: EI moderates the } \\
\text { relationship between procedural justice and } \\
\text { contextual performance but not the other justice-- } \\
\text { performance relationships. }\end{array}$ & None & $\begin{array}{l}\text { Composite EI } \\
\text { and its four } \\
\text { subdimension } \\
\text { S }\end{array}$ \\
\hline Ojedokun (2010) & $\begin{array}{l}\mathrm{N}=225 \text {, police } \\
\text { force }\end{array}$ & N/A & $\begin{array}{l}\text { Effort reward imbalance } \\
\text { concept: EIS** }\end{array}$ & $\begin{array}{l}\text { Hierarchical moderated regression: EI moderates the } \\
\text { relationship between effort-reward imbalance and }\end{array}$ & No & EI \\
\hline
\end{tabular}




\begin{tabular}{llllll}
\hline & & & & attitude toward unethical work behaviour. \\
\hline $\begin{array}{l}\text { Vigoda-Gadot } \\
\text { and Meisler } \\
(2010)\end{array}$ & $\begin{array}{l}\mathrm{N}=380, \text { public } \\
\text { sector }\end{array}$ & $\mathrm{N} / \mathrm{A}$ & EI: WLEIS** & $\begin{array}{l}\text { Hierarchical regression analysis: Moderating role of } \\
\text { EI in the relationship between organizational politics } \\
\text { and emotional commitment, as well as between } \\
\text { organizational politics and employees' absenteeism. }\end{array}$ & None \\
\hline $\begin{array}{l}\text { Kidwell } \text { et al. } \\
(2007)\end{array}$ & $\begin{array}{l}\mathrm{N}=135 \text { in 15 B2B } \\
\text { firms }\end{array}$ & $\begin{array}{l}\text { Salespeople } \\
\text { matched with } \\
\text { supervisors }\end{array}$ & EI: MSCEIT** & $\begin{array}{l}\text { Multiple regression analysis: EI moderates the } \\
\text { relationship, such that salespeople who are better at } \\
\text { perceiving customers' emotions tend to be more } \\
\text { effective when using customer-oriented behaviours } \\
\text { and adaptive selling. }\end{array}$ & None \\
\hline $\begin{array}{l}\text { Johnson and } \\
\text { Spector (2007) }\end{array}$ & $\begin{array}{l}\mathrm{N}=176 \\
\text { employees in } \\
8 \text { customer service } \\
\text { organizations }\end{array}$ & $\mathrm{N} / \mathrm{A}$ & EI: WLEIS** & $\begin{array}{l}\text { Moderator regression analysis: EI does not moderate } \\
\text { the relationship between the emotional labour and } \\
\text { personal outcomes. EI relates directly to outcomes. }\end{array}$ & $\begin{array}{l}\text { EI, gender, } \\
\text { and } \\
\text { job autonomy }\end{array}$ \\
\hline
\end{tabular}

Notes: EI = emotional intelligence; HLM = hierarchical linear modelling.

*These include data from an ability-based EI measure, the MSCEIT, supervisor ratings of salespeople and self-reported responses by salespeople.

** 16-item self-reported measure of EI, Wong and Law Emotional Intelligence Scale (WLEIS); 141 item Mayer-Salovey-Caruso emotional intelligence test (MSCEIT); 33item emotional intelligence scale (EIS) developed by Schutte et al. (1998) based on Salovey and Mayer (1990). 
Table 2 Means, standard deviations, correlations and square root of the average variance extracted

\begin{tabular}{lllllll}
\hline Variable & Mean & SD & 1 & 2 & 3 & 4 \\
\hline $\begin{array}{l}\text { 1. Salespeople's customer } \\
\text { orientation }\end{array}$ & 6.57 & .50 & .78 & & & \\
\hline $\begin{array}{l}\text { 2. Salespeople's emotional } \\
\text { intelligence }\end{array}$ & 2.07 & .53 & .26 & .73 & & \\
\hline $\begin{array}{l}\text { 3. Back-office employees' } \\
\text { emotional intelligence }\end{array}$ & 2.18 & .67 & .24 & .15 & .73 & \\
\hline $\begin{array}{l}\text { 4. Back-office employees' } \\
\text { citizenship behaviour }\end{array}$ & 1.90 & .80 & .21 & .11 & .58 & .88 \\
$\begin{array}{l}\text { Note: Values in main diagonal are the square roots of the average variance extracted; SD = standard } \\
\text { deviation. }\end{array}$
\end{tabular}

Table 3 Results of the structural model

\begin{tabular}{lc}
\hline Path & $\begin{array}{c}\text { Path coefficient } \\
(\beta)\end{array}$ \\
\hline $\begin{array}{l}\text { H1: Salespeople's customer orientation } \rightarrow \text { Organizational } \\
\text { performance }\end{array}$ & $.18^{*}$ \\
\hline $\begin{array}{l}\text { H2: Salespeople's customer orientation } \times \text { salespeople's emotional } \\
\text { intelligence } \rightarrow \text { Organizational performance }\end{array}$ & $.21^{*}$ \\
\hline $\begin{array}{l}\text { H3: Salespeople's emotional intelligence } \rightarrow \text { Back-office } \\
\text { employee's citizenship behaviour }\end{array}$ & $.29^{*}$ \\
\hline $\begin{array}{l}\text { H4: Back-office employee's emotional intelligence } \rightarrow \text { Back-office } \\
\text { employees' citizenship behaviour }\end{array}$ & $.17^{*}$ \\
\hline $\begin{array}{l}\text { H5: Salespeople's emotional intelligence } \times \text { back-office employees' } \\
\text { emotional intelligence } \rightarrow \text { Back-office employee's citizenship } \\
\text { behaviour }\end{array}$ & $.31^{*}$ \\
\hline $\begin{array}{l}\text { H6: Back-office employees' citizenship behaviour } \rightarrow \\
\text { Organizational performance }\end{array}$ & $.32^{*}$ \\
\hline$* p<.05$. &
\end{tabular}


Figure 1 Conceptual model

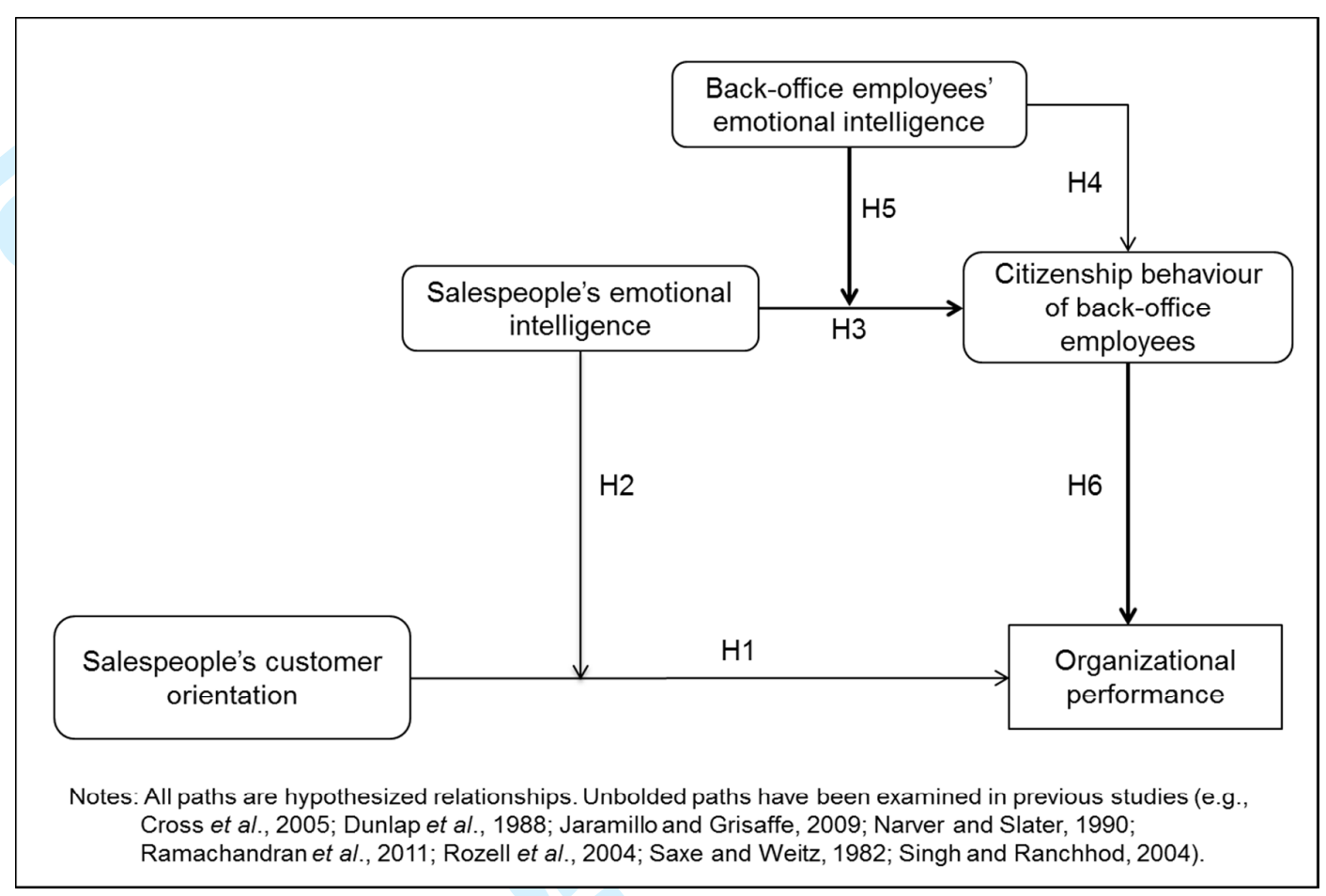




\section{Appendix}

Scales and Items Employed in the Study

\begin{tabular}{|c|c|c|c|}
\hline \multirow{2}{*}{\multicolumn{4}{|c|}{$\begin{array}{l}\text { Constructs and Measurement Items } \\
\text { Salespeople ratings: }\end{array}$}} \\
\hline & & & \\
\hline Customer orientation (Adapted from Periatt et al., 2004) & .89 & .62 & \\
\hline $\begin{array}{l}\text { Please indicate the proportion of your customers with whom } \\
\text { you act as described in the statement. }\end{array}$ & & & \\
\hline $\begin{array}{l}\text { A good salesperson* has to have the customer's best interest } \\
\text { in mind. }\end{array}$ & & & .78 \\
\hline $\begin{array}{l}\text { I offer the product/service of mine that is best suited to the } \\
\text { customer's problem. }\end{array}$ & & & .77 \\
\hline $\begin{array}{l}\text { I try to find out what kind of product/service would be most } \\
\text { helpful to a customer. }\end{array}$ & & & .84 \\
\hline $\begin{array}{l}\text { I try to bring a customer with a problem together with a } \\
\text { product/service that helps him solve that problem. }\end{array}$ & & & .73 \\
\hline I try to figure out what a customer's needs are. & & & .81 \\
\hline Emotional intelligence (Adopted from Law et al., 2004) & .92 & .53 & \\
\hline $\begin{array}{l}\text { Please indicate the degree to which you agree with the } \\
\text { following statements concerning your emotions. }\end{array}$ & & & \\
\hline Self Emotions Appraisal (SEA) & .92 & .74 & \\
\hline $\begin{array}{l}\text { I have a good sense of why I have certain feelings most of the } \\
\text { time. }\end{array}$ & & & .79 \\
\hline I have good understanding of my own emotions. & & & .91 \\
\hline I really understand what I feel. & & & .90 \\
\hline I always know whether or not I am happy. & & & .84 \\
\hline Others' Emotions Appraisal (OEA) & .91 & .73 & \\
\hline I always know my friends' emotions from their behaviour. & & & .83 \\
\hline I am a good observer of others' emotions. & & & .87 \\
\hline I am sensitive to the feelings and emotions of others. & & & .79 \\
\hline $\begin{array}{l}\text { I have good understanding of the emotions of people around } \\
\text { me. }\end{array}$ & & & .93 \\
\hline Use of Emotion (UOE) & .91 & .71 & \\
\hline $\begin{array}{l}\text { I always set goals for myself and then try my best to achieve } \\
\text { them. }\end{array}$ & & & .78 \\
\hline I always tell myself I am a competent person. & & & .81 \\
\hline I am a self-motivating person. & & & .89 \\
\hline I would always encourage myself to try my best. & & & .87 \\
\hline Regulation of Emotion (ROE) & .92 & .75 & \\
\hline $\begin{array}{l}\text { I am able to control my temper so that I can handle difficulties } \\
\text { rationally. }\end{array}$ & & & .86 \\
\hline I am quite capable of controlling my own emotions. & & & .87 \\
\hline I can always calm down quickly when I am very angry. & & & .79 \\
\hline I have good control of my own emotions. & & & .93 \\
\hline Back-office employees ratings: & & & \\
\hline Emotional intelligence (Adopted from Law et al., 2004) & .92 & .53 & \\
\hline $\begin{array}{l}\text { Please indicate the degree to which you agree with the } \\
\text { following statements concerning your emotions. }\end{array}$ & & & \\
\hline Self Emotions Appraisal (SEA) & .92 & .75 & \\
\hline $\begin{array}{l}\text { I have a good sense of why I have certain feelings most of the } \\
\text { time. }\end{array}$ & & & .83 \\
\hline
\end{tabular}


I have good understanding of my own emotions.

I really understand what I feel.

I always know whether or not I am happy.

Others' Emotions Appraisal (OEA)

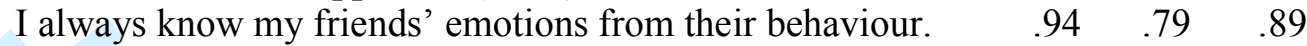

I am a good observer of others' emotions.

.91

I am sensitive to the feelings and emotions of others.

.82

I have good understanding of the emotions of people around

me.

Use of Emotion (UOE)

$\begin{array}{lllll}\text { I always set goals for myself and then try my best to achieve } & .89 & .66 & .84\end{array}$ them.

I always tell myself I am a competent person. $\quad .73$

I am a self-motivating person. $\quad .87$

I would always encourage myself to try my best. $\quad .80$

Regulation of Emotion (ROE)

$\begin{array}{llll}\text { I am able to control my temper so that I can handle difficulties } & .95 & .83 & .90\end{array}$ rationally.

I am quite capable of controlling my own emotions.

.94

I can always calm down quickly when I am very angry.

I have good control of my own emotions.

Employee citizenship behaviour (adopted from Bettencourt and Brown, 1997)

Please indicate the extent to which you agree with the

following statements regarding your job.

I voluntary assist the customers even if it means going beyond

job requirements.

I helps customers with problems beyond what is expected or

required.

I often go above beyond the call of duty when serving

customers.

I willingly go of my way to make a customer satisfied.

* The term employee in the original scale was changed to 'salesperson' for this study. 